\title{
LIFE CYCLE ASSESSMENT (LCA) OF WINTER WHEAT IN AN INTENSIVE CROP PRODUCTION SYSTEM IN WIELKOPOLSKA REGION (POLAND)
}

\author{
HOLKA, M. ${ }^{1}$ - JANKOWIAK, J. ${ }^{1}$ - BIEŃKOWSKI, J. F. ${ }^{1 *}$ - DĄBROWICZ, R. ${ }^{1}$ \\ ${ }^{1}$ Institute for Agricultural and Forest Environment Polish Academy of Sciences, Department of \\ Agricultural Systems, Bukowska 19, 60-809 Poznań, Poland \\ (phonelfax: +48-61-868-17-30) \\ *Corresponding author \\ e-mail: bjerzy@onet.pl \\ (Received 22 $2^{\text {nd }}$ Sep 2015; accepted 30 ${ }^{\text {th }}$ May 2016)
}

\begin{abstract}
This study aimed to assess the environmental impact of winter wheat production in an intensive crop production system. In view of environmental concerns linked to modern practices of crop production, it is necessary to identify the ecological profile of highly productive winter wheat. The life cycle assessment (LCA) of this crop was performed in two large-scale farms, located in the Wielkopolska region (Poland), in the years 2011-2013. Results obtained indicated that the core processes related to wheat production on the farm had the biggest influence on acidification, eutrophication and global warming potentials. The possibility of photochemical ozone creation and depletion of abiotic resources, such as minerals and fossil fuels, were most dependent on the upstream processes. The mineral fertilization process was identified as the most important source of environmental threats. The grain transport stage had the lowest share in all analyzed impact category indicators. Normalization showed that acidification attributed to wheat production had the greatest environmental impact on the overall environmental profile. This indicates that the priority direction in mitigation of environmental impacts associated with intensive wheat production should be lowering adverse effect on soil acidification, followed by global warming and eutrophication.
\end{abstract}

Keywords: agriculture, environment, impact category indicators, life cycle stages, grain crop

\section{Introduction}

Cereal production is one of the most important agricultural activities in Poland. The share of cereals in the total cropping patterns is around $73 \%$ (CSO, 2014). In cereal cultivation, wheat is a dominant crop. Its acreage decreased by $19 \%$ over the years 2000-2013 and occupied 2138 thous. ha in 2013 (LDB CSO, 2015). Despite this drop, an upward trend in its production output has been observed. This was caused by an increase in yield by nearly $38 \%$, up to $44.4 \mathrm{dt}$ per hectare. Yield increases are still below the wheat yielding potential, which in favourable edaphic and climatic conditions as well as in modern cultivation technology can reach the level of $120 \mathrm{dt}$ per hectare in Poland (Weber at al., 2011). Utilization of modern agricultural machinery, mineral fertilizers and pesticides contributed to the intensification of production and higher yields. However, the result of this process may have an adverse impact on the environment. The use of large amounts of industrial means of production in farming contributes largely to the depletion of non-renewable resources, an increase in greenhouse gas (GHG) emissions, and pollution from chemical substances that can lead to soil acidification and eutrophication (Bieńkowski et al., 2014; Nemecek et al., 2011).

Striving for lower emissions of gaseous pollutants and improvements in the use of natural resources and energy has been emphasized by strategies for sustainable development and use of renewable energy. It caused an increased interest in methods 
for environmental impact assessments in the EU, such as the LCA (Life Cycle Assessment) (Hontelez and Buitenkamp, 2006; EC, 2013; European Council Conclusions, 2014). This method allows for an analysis of the potential environmental risks throughout the life cycle of a product, i.e. from the extraction of raw materials, their processing and transport, through the production, distribution and utilization, until the final waste management. It was created primarily for the needs of the industry, but it has also become a useful tool in the agricultural sector (Caffrey and Veal, 2013). The results obtained at the production stage of primarily raw materials are essential for the future analysis of the final products, manufactured in the agri-food industry (Roy et al., 2009). In order to achieve reliable and accurate results using the life cycle analysis, research at the regional and national level should be conducted. Using data of global significance does not allow for an objective assessment due to the differentiation of production conditions across world (Biswas and John, 2009).

Application of the LCA method in the assessment of environmental effects of cereals production in Poland will allow to identify the most hazardous parts of the production cycle. It will create the basis for improving technology of production process, for the environment and farmers' benefits. The aim of the study was to determine the environmental impact of winter wheat grown in an intensive production system, considered to be the most representative production type of this crop in the Wielkopolska region.

\section{Materials and methods}

The materials used for the analysis are data from two agricultural farms: Trzebiny (Farm 1) and Dhugie Stare (Farm 2), located in the south-western part of the Wielkopolska region (Poland), during the period 2011-2013. The region is distinguished by high technical efficiencies in plant and livestock production, as well as by a large agricultural commodity output compared to other ones (Bieńkowski and Jankowiak, 2006). Farms are part of the Długie Stare Agricultural Company Ltd., a subsidiary of the State Treasury, which belongs to a small group of strategic state-owned companies. The company focuses on crop production including cereals, oilseed rape, sugar beet and in livestock farming - dairy cows and beef cattle. It achieves good production results in both crop and animal farming. It is very well organized in terms of balance between the main branches of production.

Each of the studied farms has area of about 500 hectares of agricultural land (AL) (Table 1). They run intensive agricultural production, as evidenced by high levels of mineral fertilizers (NPK), compared to lower fertilization in Poland with an average of $129.3 \mathrm{~kg} \mathrm{ha}^{-1} \mathrm{AL}$ (CSO, 2014). Farm 1 had markedly higher variability of NPK fertilization. The reason for that was a drop in the use of phosphorus and potassium fertilizers during the research period after determined build up of soil phosphorus and potassium reserves. Total cereal yields in the analyzed period in both farms were higher than the average yield in the country (by $54.8 \%$ in Farm 1 and by $80.6 \%$ in Farm 2). Livestock density was more than 2-fold lower than the upper limit of $1.5 \mathrm{DJP}^{-1} \mathrm{AL}$, which is recommended for environmental reasons by a code of good agricultural practices (Duer et al., 2004). The share of cereals in cropping patterns ranged from 51.9 to $61.1 \%$. Industrial plants, including root and oil crops, accounted for $16.5 \%$ in Farm 1 and $27.0 \%$ in Farm 2. High overall intensity of farm management and the importance of livestock processes have also been reflected by the presence of the annual and the 
perennial fodder crops (in total $18.1 \%$ of AL in the Farm 1 and $21.1 \%$ of AL in the Farm 2).

Table 1. Characterization of studied farms (averages for the years 2011-2013 \pm standard deviation)

\begin{tabular}{|c|c|c|}
\hline Specification & Farm 1 & Farm 2 \\
\hline Area AL (ha) & 492.29 & 516.24 \\
\hline Soil valuation index (points) & 0.67 & 1.21 \\
\hline NPK ferilization $\left(\mathrm{kg} \mathrm{ha}^{-1} \mathrm{AL}\right)$ & $245.94 \pm 43.61$ & $269.80 \pm 14.71$ \\
\hline Livestock density $\left(\mathrm{AU} \mathrm{ha}^{-1}\right)$ & $0.66 \pm 0.01$ & $0.72 \pm 0.03$ \\
\hline Cereal yield $\left(\mathrm{dt} \mathrm{ha}^{-1}\right)$ & $56.4 \pm 5.1$ & $65.8 \pm 2.3$ \\
\hline \multicolumn{3}{|l|}{ Cropping pattern (\%) } \\
\hline - cereals & $61.1 \pm 8.2$ & $51.9 \pm 5.5$ \\
\hline - root crops & $7.9 \pm 1.2$ & $12.0 \pm 4.4$ \\
\hline - oil plants & $12.9 \pm 10.7$ & $15.0 \pm 8.1$ \\
\hline - annual fodder crops & $13.4 \pm 4.6$ & $10.6 \pm 6.9$ \\
\hline - perennial fodder crops & $4.7 \pm 4.1$ & $10.5 \pm 0$ \\
\hline
\end{tabular}

Data for the analysis came from the source documents of the farms. They were collected in specially prepared registration forms and supplemented with interviews among the farms' managers. Additional sources of information were the accounting documents and the technical documentation of agricultural machines and vehicles. The collected data included all production inputs, such as seeds, fertilizers, pesticides, fuel, engine oil, grease, electricity, plus a detailed characterization of tractors and machines. Data on type and duration of technological operations were collected systematically during the development of the field works.

The LCA method used in this study was composed of four phases: 1) goal and scope definition, 2) inventory analysis, 3) impact assessment and 4) interpretation (Brentrup et al., 2004a). In the first phase, the following elements were defined: the purpose, system boundaries, assumptions, limitations and functional unit. The analysis of a set of inputs and outputs, i.e. life cycle inventory (LCI), is featured by collecting quality and quantity data of used materials and energy, production results and estimated emissions. They constitute the basis for the life cycle impact assessment (LCIA), in which after the selection of category and category indicators, the classification and characterization procedures are performed. In the last phase, conclusions are made, according to the predetermined purpose of the study (interpretation).

The study was carried out from "cradle-to-farm gate", i.e. from manufacturing of means of agricultural production, through the process of field cultivation, harvesting and grain transport to the customer (in this case, it was the company that exports cereals), without the stage of use and waste management. Two functional units were used: 1.0 hectare - expressing the intensity of the wheat production system, and 1.0 ton of grain, which is a measure of its efficiency, quantitatively characterizing the product with reference flow specifically estimated for this unit. The CML methodology based on midpoint approach was applied in the LCIA (phase 3) (Guinée et al., 2002). The impact assessment included the following environmental categories indicators: global warming potential $\left(\mathrm{GWP}_{100}\right)$, eutrophication potential (EP), acidification potential (AP), photochemical ozone creation potential (POCP), abiotic resources depletion potential for minerals (ADP minerals) and for fossil fuels (ADP fossil fuel), as well as land use and pesticide use. 
Impacts for the categories of climate change, soil and water acidification, eutrophication, the formation of photochemical oxidants and depletion of abiotic resources were calculated by using the following formula (Guinée et al., 2002):

$$
I_{c a t}=\sum_{i}\left(m_{i} \cdot C F_{c a t, i}\right)
$$

where $\mathrm{I}_{\text {cat }}$ is an impact category indicator, $\mathrm{m}_{\mathrm{i}}$ - the amount of the $\mathrm{i}$-th substance used or emitted, $\mathrm{CF}_{\text {cat, } \mathrm{i}}$ - an impact category characterization factor of the substance.

The use of land was expressed by the indicator calculated as the ratio of surface unit and the yield obtained.

To widen interpretation of the results a normalization procedure was carried out. It is an optional step of the LCIA phase and consists in the presentation of the participation of the specific impact in the general environmental problem. Normalized impact category indicators $\left(\mathrm{NI}_{\text {cat }}\right)$ were calculated as the ratio of the product of the average indicator value for farms $\left(\mathrm{I}_{\mathrm{cat}}\right)$ and the size of the winter wheat production in Europe $(\mathrm{P})$, to the value of the impact category reference indicator in Europe for the year 2005 (IR $\mathrm{IR}_{\text {cat }}$ (Sleeswijk et al., 2008), as shown in the equation below:

$$
N I_{c a t}=\frac{I_{c a t} \cdot P}{I R_{c a t}}
$$

Within the system, there were distinguished three stages of the life cycle: upstream, core and downstream processes (Fig. 1). Production and distribution of the means of agricultural production, including: energy, agricultural machinery, agrochemicals and seeds were analyzed within the upstream processes. The core processes included wheat production on the farm and consisted of the following processes: cultivation, seeding, fertilization, pest management, harvesting and internal transport. Analysis of the downstream processes focused on the grain transport for sale. Environmental effects of each process were investigated on the basis of materials and energy inputs, as well as emissions of mineral substances to the soil environment and gases into the atmosphere. The impact category indicators for the upstream processes were calculated using information provided by the manufacturer, literature sources (Jayasundara et al., 2014; Lillywhite et al., 2007) and AGRIBALYSE ${ }^{\circledR}$ database (Colomb et al., 2013). Agricultural production processes were evaluated on the basis of detailed data from the farms. Methods for calculating direct and indirect emissions of $\mathrm{N}_{2} \mathrm{O}$ from fertilizers were adopted in accordance with IPCC (2006) and the Emission Inventory Guidebook (EMEP/EEA, 2013). Emissions from combustion of fuel during field and transport operations were estimated, according to the amount of fuel consumed and emission factors given by the EMEP/EEA (2013). Data for wheat production in Poland and Europe were collected from LDB CSO (2015) and EUROSTAT (2015) databases. 


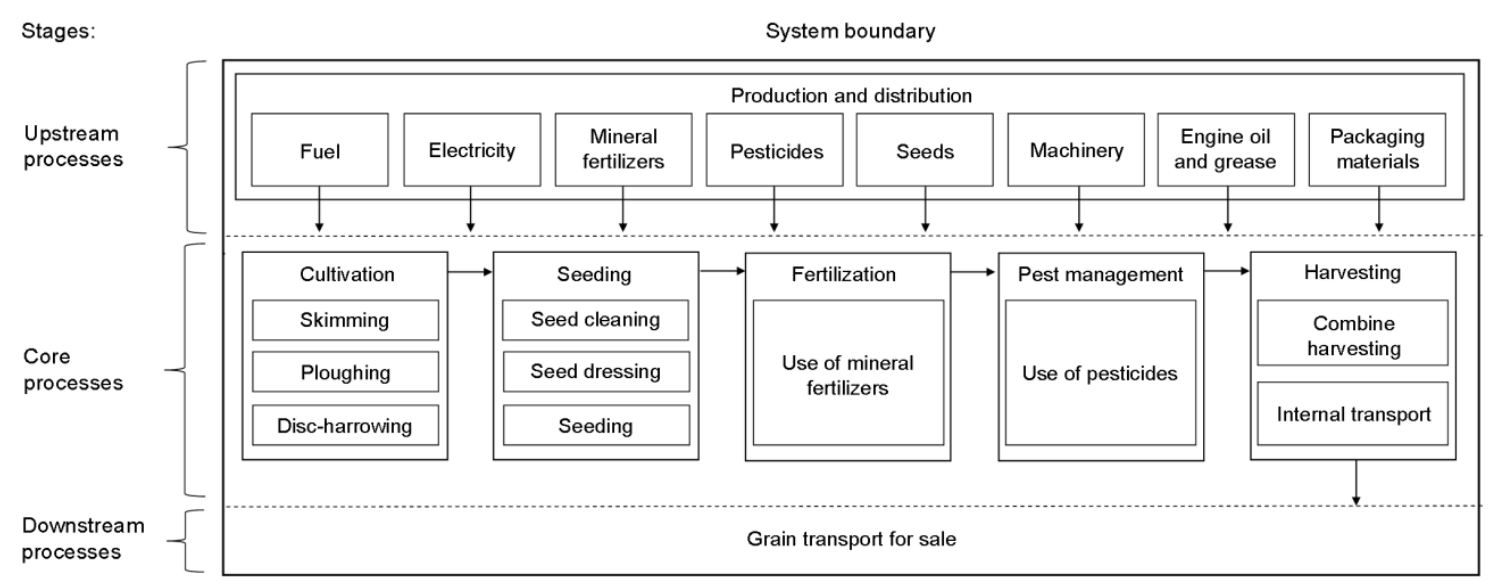

Figure 1. Schematic diagram of processes according to life cycle stages within the analyzed wheat production system

\section{Results and discussion}

Inventory databases of production processes were created on the basis of information collected from the farms. Quantities of utilized materials and energy were used as the input data for the LCI phase. Farm 2 used higher amounts of inputs per 1.0 hectare of crop area than Farm 1 (Table 2). This has been reflected by the calculated impact category indicators, which are presented in Table 3. Higher values in relation to the functional units of 1.0 hectare of area and 1.0 ton of grain were noted in the Farm 2. It can be assumed that this resulted mainly from the differences in the amount of applied nutrient between farms. The average value of $\mathrm{GWP}_{100}$ indicator per 1 ha amounted to $2457.5 \mathrm{~kg} \mathrm{CO}$ eq., and in terms of $1 \mathrm{t}$ of grain $-364.1 \mathrm{~kg} \mathrm{CO}_{2}$ eq. It is comparable with results obtained by Charles et al. (2006). While AP and EP indicators for wheat in these farms were two and three times higher than the data from this literature source indicated. The type of nitrogen fertilizers consumed was presumably most responsible for the estimated potentials of acidification and eutrophication. Around $78 \%$ of nitrogen applied to winter wheat came from the nitrogen solution (data not presented). According to data reported in literature, $8 \%$ of nitrogen in this fertilizer is subject to volatilization loss in the form of ammonia (EMEP/EEA, 2013). A high ammonia emission during the fertilization process makes the most important contribution to these impact categories. While planning to introduce improvements in fertilizer management, the most important issue would be displacing liquid nitrogen fertilizer with another one with low on-field nitrogen emission. In the case of analysis of the environmental impact of wheat production in Chile, the impact indicators for 1.0 ton of grain were even higher: $\mathrm{GWP}_{100}$ - $792.76 \mathrm{~kg} \mathrm{CO}_{2}$ eq., $\mathrm{AP}-15.28 \mathrm{~kg} \mathrm{SO}_{2}$ eq. and $\mathrm{EP}-4.83 \mathrm{~kg} \mathrm{PO}_{4}{ }^{-3}$ eq. (Huerta et al., 2012). Considering the land use by both farms, it can be assumed that the lower value of this indicator was due to poorer soil quality in Farm 1 than in Farm 2 (Table 1). Hence, the differences in productivity of soils which are directly linked with land use could also be explained by the influence of the same factor.

Application of large amounts of pesticides causes the risk of their leakage into surface water and groundwater, air and food products, as well as the reduction of biodiversity in agricultural landscape (Wattiez and Wiliamson, 2003). The average amount of pesticides used in wheat protection treatments for the farms was $3.2 \mathrm{~kg}$ a.i. 
$\mathrm{ha}^{-1}$. The application rate was higher than in Poland and Europe, where the estimated levels of plant protection product used were 1.9 and $2.3 \mathrm{~kg}$ a.i. ha ${ }^{-1}$, respectively (Syp et al., 2012).

Table 2. Inventory data of agricultural inputs by 1 ha of winter wheat in the analyzed farms (averages for the years 2011-2013 \pm standard deviation)

\begin{tabular}{l|c|c|c}
\hline \multicolumn{1}{c|}{ Type of input } & Unit & Farm 1 & Farm 2 \\
\hline Seeds & $\mathrm{kg}$ & $182.0 \pm 5.5$ & $168.9 \pm 6.0$ \\
Fertilizers & $\mathrm{kg}$ & $159.6 \pm 8.1$ & $229.8 \pm 6.6$ \\
- nitrogen $(\mathrm{N})$ & $\mathrm{kg}$ & $8.1 \pm 4.2$ & $17.7 \pm 2.5$ \\
- phosphorous $\left(\mathrm{P}_{2} \mathrm{O}_{5}\right)$ & $\mathrm{kg}$ & $29.2 \pm 11.6$ & $58.7 \pm 7.6$ \\
- potassium $\left(\mathrm{K}_{2} \mathrm{O}\right)$ & & & \\
Pesticides & $\mathrm{kg}$ & $1.5 \pm 0.6$ & $2.1 \pm 2.2$ \\
- herbicides (a.i.) & $\mathrm{kg}$ & $0.8 \pm 0.1$ & $0.7 \pm 0.4$ \\
- fungicides (a.i.) & $\mathrm{kg}$ & $0.2 \pm 0.1$ & $0.0 \pm 0.0$ \\
- insecticides (a.i.) & $\mathrm{kg}$ & $0.5 \pm 0.0$ & $0.5 \pm 0.0$ \\
- plant growth regulators (a.i.) & $\mathrm{kg}$ & $10.8 \pm 3.5$ & $7.6 \pm 3.3$ \\
Tractors and mobile machinery & $\mathrm{kg}$ & $10.7 \pm 2.1$ & $9.2 \pm 2.1$ \\
Machines and equipment & $\mathrm{kg}$ & $6.7 \pm 1.7$ & $5.3 \pm 1.5$ \\
Spare parts and materials for the repair & $\mathrm{kWh}$ & $2.9 \pm 0.5$ & $2.8 \pm 0.5$ \\
Electricity & 1 & $98.0 \pm 4.4$ & $109.4 \pm 5.8$ \\
Diesel oil & 1 & $0.6 \pm 0.1$ & $1.0 \pm 0.2$ \\
Gear oil & 1 & $1.0 \pm 0.1$ & $0.7 \pm 0.1$ \\
Engine oil & 1 & $0.4 \pm 0.0$ & $0.4 \pm 0.0$ \\
Liquid refrigerant and others & $\mathrm{m}^{2}$ & $176.8 \pm 0.9$ & $217.7 \pm 1.3$ \\
Polyethylene mesh & $\mathrm{kg}$ & $0.8 \pm 0.2$ & $0.9 \pm 0.2$ \\
500 kg polypropylene woven bag & & & \\
\hline
\end{tabular}

Table 3. Impact category indicators of the winter wheat production per functional units in analyzed farms (averages for the years 2011-2013)

\begin{tabular}{|c|c|c|c|c|c|c|}
\hline \multirow{3}{*}{ Impact category indicators } & \multicolumn{2}{|c|}{ Farm 1} & \multicolumn{2}{|c|}{ Farm 2} & \multicolumn{2}{|c|}{ Mean } \\
\hline & \multicolumn{6}{|c|}{ Functional unit } \\
\hline & 1 ha & $1 \mathrm{t}$ & 1 ha & $1 \mathrm{t}$ & 1 ha & $1 \mathrm{t}$ \\
\hline $\mathrm{GWP}_{100}, \mathrm{~kg} \mathrm{CO}_{2}$ eq. & 2173.1 & 323.9 & 2742.0 & 404.4 & 2457.5 & 364.1 \\
\hline $\mathrm{AP}, \mathrm{kg} \mathrm{SO}{ }_{2}$ eq. & 30.8 & 4.6 & 44.5 & 6.6 & 37.6 & 5.6 \\
\hline $\mathrm{EP}, \mathrm{kg} \mathrm{PO}_{4}^{-3}$ eq. & 8.8 & 1.3 & 12.0 & 1.8 & 10.4 & 1.5 \\
\hline POCP, $\mathrm{kg} \mathrm{C}_{2} \mathrm{H}_{4}$ eq. & 0.5 & 0.1 & 0.6 & 0.1 & 0.6 & 0.1 \\
\hline ADP minerals, $\mathrm{kg}$ Sb eq. & 0.013 & 0.002 & 0.020 & 0.003 & 0.016 & 0.002 \\
\hline ADP fossil fuel, $\mathrm{kg} \mathrm{Sb}$ eq. & 3.3 & 0.5 & 4.2 & 0.6 & 3.7 & 0.6 \\
\hline Land use, ha $\mathrm{t}^{-1} \mathrm{yr}^{-1}$ & . & 0.149 & . & 0.147 & - & 0.148 \\
\hline Use of pesticide, $\mathrm{kg}$ a.i. & 3.0 & 0.4 & 3.3 & 0.5 & 3.15 & 0.45 \\
\hline
\end{tabular}

The results showed that among all the technological processes of the analyzed system, the largest influence on the formation of potential environmental impacts had mineral fertilization (Fig. 2). Cultivation, sowing and harvesting affected environment to a lesser extent. Plant protection and grain transport had a relatively minor impact. In New Zealand, $52 \%$ of the overall amount of GHG emissions from wheat cultivation 
were caused by fertilization, including $48 \%$ by nitrogen fertilizer (Safa and Samarasinghe, 2012). Biswas et al. (2010) comparing two phases of wheat production in Australia: the upstream and core processes found that their share in the total GHG emissions amounted to $2.6 \%$ and $97.4 \%$, respectively, out of which $59 \%$ originated from $\mathrm{N}_{2} \mathrm{O}$ emissions from the soil.

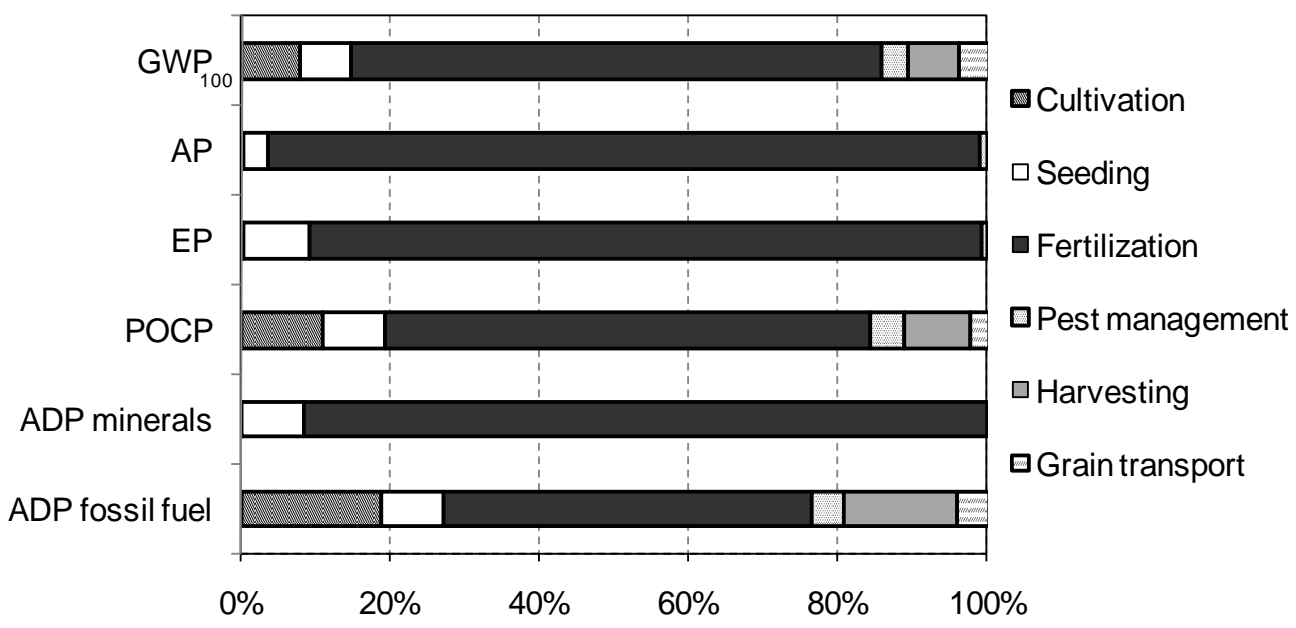

Figure 2. Relative contribution of technological processes in wheat production to the impact category indicators (averages for the farms and the years 2011-2013)

Roer et al. (2012) noted that emissions from fields had a remarkable contribution in the indicators of POCP and soil AP, of above 60\%. Their studies, indicated that manufacturing and utilization of production means had approximately $50 \%$ share in the total value of the ADP mineral, $30 \%$ of which was generated by the production of nitrogen fertilizers. In turn, the phosphate fertilizers production was quite important for the caused environmental impact associated with eutrophication, contributing above $30 \%$ to the indicator of EP.

The indicators of the GWP $\mathrm{GW0}_{100}$ AP and EP depended mainly on the core processes in the wheat life cycle, which included transport of production means to the farm, cultivation and harvest (Fig. 3). At the same time, POCP and ADP mineral were related largely to the production of agricultural means in the upstream processes. The stage of downstream processes had a small part in the formation of the analyzed environmental impacts. In this stage, emissions from fuel combustion and the production of tractors and machines used in grain transport had a significant effect only for $\mathrm{GWP}_{100}$, ADP and POCP. The main factor determining the impact of the processes in this stage is the distance of transport (Meisterling et al., 2009).

An average indicator of land use in farms per $1 \mathrm{t}$ of produced wheat grain had a value of 0.15 ha year ${ }^{-1}$ and was lower, compared to the same indicators calculated for Poland (37.5\%) and the European Union (16.7\%) (Fig. 4). Brentrup et al. (2004b) demonstrated that the utilization of land resources for this purpose improves with increasing intensity of fertilization. It should be noted that the observed differences in the results of this indicator may be due not only to the type of used technology but also to the natural environmental conditions, such as soil quality, climate, terrain relief and water conditions, which determine the potential productivity of crop plants. Schenck et al. 
(2008) confirmed this by showing dependence of the yield and land use indicator on the influence of the sum of natural rainfall.

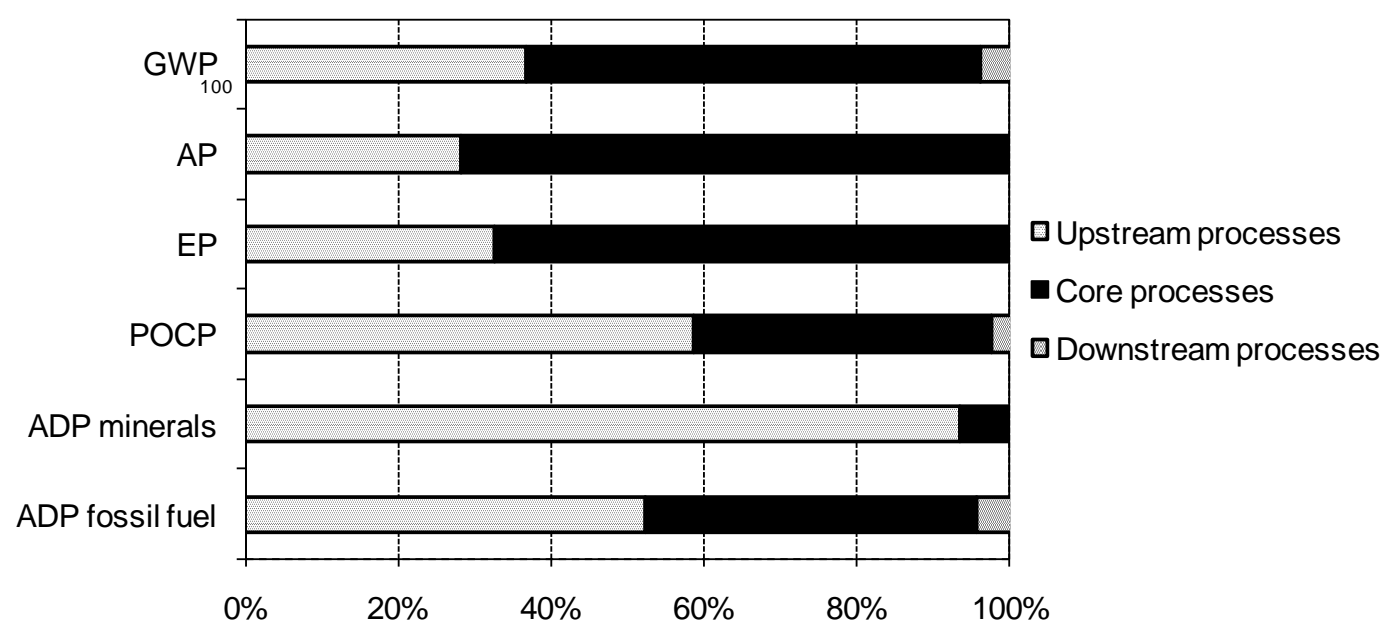

Figure 3. Share of life cycle stages in wheat production for the analyzed environmental impacts (averages for the farms and the years 2011-2013)

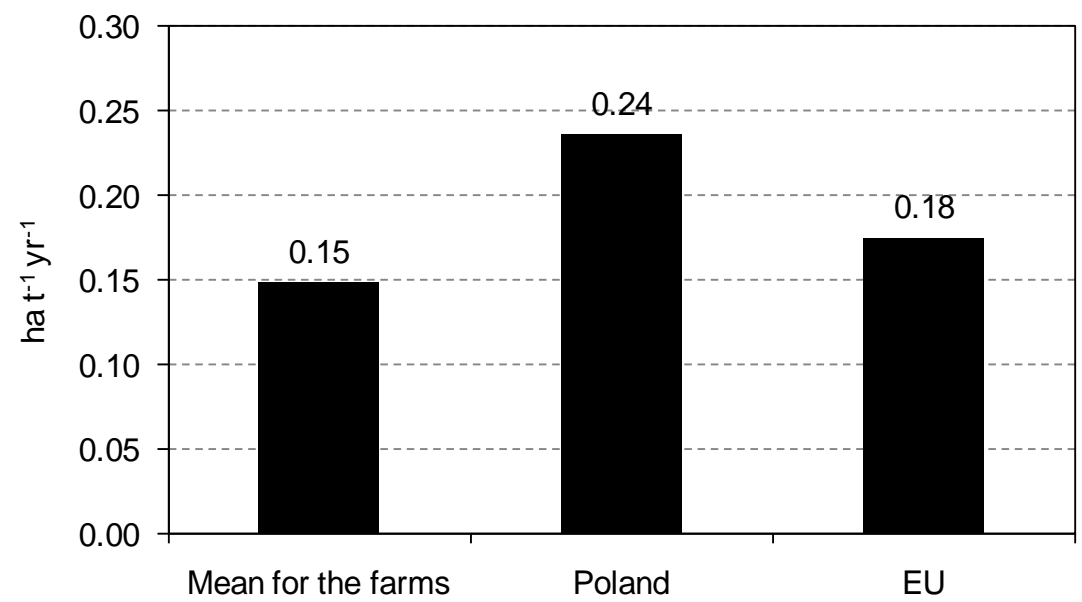

Figure 4. Land use indicator of winter wheat production in the analyzed farms, Poland and EU (averages for the years 2011-2013)

Considering results of normalization, it can be concluded that the biggest environmental risk linked to the intensive wheat production system, in the overall environmental profile, is associated with soil acidification (Fig. 5). The analyzed production system showed also a relatively large impact on the greenhouse effect and eutrophication. Similar results were also obtained by Huerta et al. (2012) after normalization data with world values. 


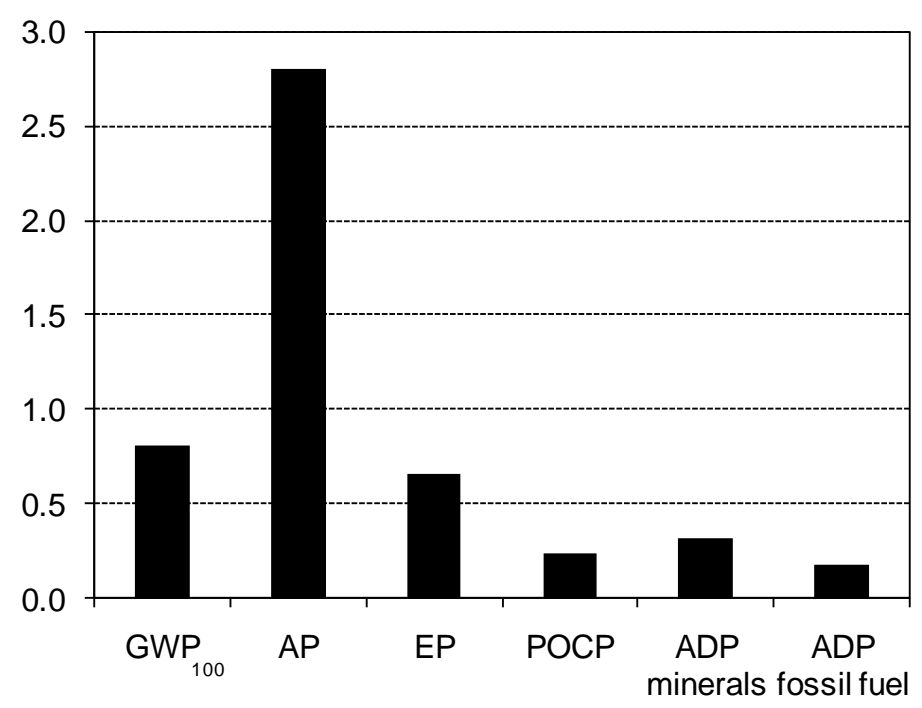

Figure 5. Normalized environmental effects of winter wheat production in the analyzed farms (averages for the years 2011-2013)

\section{Conclusions}

Different streams of materials and energy were used in the upstream, core and downstream processes of wheat production. The negative effect of these processes are environmentally harmful emissions. In view of the EU policy requirements in the field of environmental protection, there is necessity to look for new solutions limiting the formation of environmental threats associated with an intensive wheat production. LCA indicates environmental hotspots of the product chain of wheat. This allows to indentify the places and to determine ways to reduce the environmental impact.

The analysis of winter wheat production impact on the environment showed that in the development of more environmentally friendly technologies, emission risks related to the use of mineral fertilizers have to be taken into account. The precise application technology and optimization of fertilization could be very important advances for reducing emissions from the fields and lowering the consumption of raw materials in the fertilizer manufacturing. Implementing reduced tillage systems in grain production in the Wielkopolska region may also reduce the use of fossil fuels and GHG emissions from fuel. In addition to technological solutions on farms, we should also seek the opportunities to increase technical efficiency at the stage of manufacturing the agricultural inputs in industrial processes. Taking into account the results of normalization, the most important impact category of wheat production, in terms of the overall environmental profile, was the acidification, followed by greenhouse effect and eutrophication.

Life cycle analysis of winter wheat cultivation in intensive production system provides relevant inventory data for the national area that can be used in the foodprocessing sector. They are source basis for the environmental assessment of products in the country for which wheat is the raw material in industrial processing. 


\section{REFERENCES}

[1] Bieńkowski, J., Jankowiak, J. (2006): Sustainable farming in the Wielkopolska Region economic and environmental perspective. p. 130-141. - In: Kundzewicz, Z. W., Hattermann, F. F. (eds.) Natural Systems and Global Change. Research Centre for Agricultural and Forest Environment of the Polish Academy of Sciences, Potsdam Institute for Climate Impact Research, Poznan, Poland, Potsdam, Germany.

[2] Bieńkowski, J., Jankowiak, J., Dąbrowicz, R., Holka, M. (2014): Regional differentiation of greenhouse gas emissions from agriculture in Poland. Abstract 425-26. - In: Pepó, P., Csajbók, J. (eds.) Book of Abstracts, ESA XIIIth Congress, Debrecen, Hungary. 25-29 August. University of Debrecen, Debrecen, Hungary.

[3] Biswas, W. K., Graham, J., Kelly, K., John, M. B. (2010): Global warming contributions from wheat, sheep meat and wool production in Victoria, Australia - a life cycle assessment - Journal of Cleaner Production 18: 1386-1392.

[4] Biswas, W., John, M. (2009): Review of life-cycle assessment research for the Australian grain industries - $\mathrm{CAB}$ Reviews: Perspectives in Agriculture, Veterinary Science, Nutrition and Natural Resources 4(16): 1-7.

[5] Brentrup, F., Küsters, J., Kuhlmann, H., Lammel, J. (2004a): Environmental impact assessment of agricultural production systems using the life cycle assessment methodology I. Theoretical concept of a LCA method tailored to crop production European Journal of Agronomy 20: 247-264.

[6] Brentrup, F., Küsters, J., Lammel, J., Barraclough, P., Kuhlmann, H. (2004b): Environmental impact assessment of agricultural production systems using the life cycle assessment (LCA) methodology. II. The application to $\mathrm{N}$ fertilizers use in winter wheat production systems - European Journal of Agronomy 20: 265-279.

[7] Caffrey, K. R., Veal, M. W. (2013): Conducting an Agricultural Life Cycle Assessment: Challenges and Perspectives - The Scientific World Journal: 1-13. Available at: http://dx.doi.org/10.1155/2013/472431 (accessed March 2015).

[8] Charles, R., Jolliet, O., Gaillard, G., Pellet, D. (2006): Environmental analysis of intensity level in wheat crop production using life cycle assessment - Agriculture, Ecosystems and Environment 113: 216-225.

[9] Colomb, V., Aït-Amar, S., Basset-Mens, C., Dollé, J. B., Gac, A., Gaillard, G., Koch, P., Lellahi, A., Mousset, J., Salou, T., Tailleur, A., van der Werf, H. (2013): AGRIBALYSE $^{\circledR}$ : Assessment and lessons for the future, Version 1.0. ADEME, Angers, France.

[10] CSO (2014): Statistical Yearbook of the Republic of Poland 2014. Warsaw.

[11] Duer, I., Fotyma, M., Madej, A. (2004): Code of Good Agricultural Practice. - Ministry of Agriculture and Rural Development, Ministry of the Environment, Warsaw, Poland. [In Polish]

[12] EC (2013): Commission Recommendation of 9 April 2013 on the use of common methods to measure and communicate the life cycle environmental performance of products and organizations. Official Journal of the European Union L124: 1-210.

[13] EMEP/EEA (2013): Air Pollutant Emission Inventory Guidebook. Technical guidance to prepare national emission inventories. EEA technical report no 12/2013. EEA, Copenhagen, Denmark.

[14] European Council Conclusions (2014): 2030 Climate and energy policy framework. Conclusions - 23/24 October 2014, EUCO 169/14. Available at http://www.consilium. europa.eu/uedocs/cms_data/docs/pressdata/en/ec/145397.pdf (accessed March 2015).

[15] EUROSTAT (2015): Agriculture and Fisheries Database. Available at http://ec.europa.eu/eurostat/web/agriculture/data/database (accessed March 2015).

[16] Guinée, J. B., Gorrée, M., Heijungs, R., Huppes, G., Kleijn, R., de Koning, A., van Oers, L., Wegener Sleeswijk, A., Suh, S., Udo de Haes, H. A., de Bruijn, H., van Duin, R., Huijbregts, M. A. J. (2002): Handbook on life cycle assessment. Operational guide to the 
ISO standards. I: LCA in perspective. IIa: Guide. IIb: Operational annex. III: Scientific background. Kluwer Academic Publishers, Dordrecht, Netherlands.

[17] Hontelez, J., Buitenkamp, M. (2006): EU sustainable development strategy. From theory to delivery. EEB, Brussels, Belgium.

[18] Huerta, J. H., Alvear, E. M., Navarro, R. M. (2012): Evaluation of two production methods of Chilean wheat by life cycle assessment (LCA) - IDESIA 30(2): 101-110.

[19] IPCC (2006): 2006 IPCC Guidelines for National Greenhouse Gas Inventories. Volume 4 Agriculture, Forestry and Other Land Use, http://www.ipcc-nggip. iges.or.jp /public/2006gl/vol4.html (accessed March 2015).

[20] Jayasundara, S., Wagner-Riddle, C., Dias, G., Kariyapperuma, K. A. (2014): Energy and greenhouse gas intensity of corn (Zea mays L.) production in Ontario: A regional assessment - Canadian Journal of Soil Science 94: 77-95.

[21] LDB CSO (2015): Local Data Bank, Central Statistical Office of Poland, Warsaw. Available at http://stat.gov.pl/bdl (accessed March 2015).

[22] Lillywhite, R., Chandler, D., Grant, W., Lewis, K., Firth, C., Schmutz, U., Halpin, D. (2007): Environmental footprint and sustainability of horticulture (including potatoes) - a comparison with other agricultural sectors. - University of Warwick, Warwick, Defra, London, United Kingdom.

[23] Meisterling, K., Samaras, C., Schweizer, V. (2009): Decisions to reduce greenhouse gases from agriculture and product transport: LCA case study of organic and conventional wheat - Journal of Cleaner Production 17: 222-230.

[24] Nemecek, T., Huguenin-Elie, O., Dubois, D., Gaillard, G., Schaller, B., Chervet, A. (2011): Life cycle assessment of Swiss farming systems: II. Extensive and intensive production - Agricultural Systems 104: 233-245.

[25] Roer, A.-G., Korsaeth, A., Henriksen, T. M., Michelsen, O., Strømman, A. H. (2012): The influence of system boundaries on life cycle assessment of grain production in central southeast Norway - Agricultural Systems 111: 75-84.

[26] Roy, P., Nei, D., Orikasa, T., Xu, Q., Okadome, H., Nakamur, N., Shiina, T. 2009. A review of life cycle assessment (LCA) on some food products - Journal of Food Engineering 90: 1-10.

[27] Safa, M., Samarasinghe, S. (2012): $\mathrm{CO}_{2}$ emissions from farm inputs Case study of wheat production in Canterbury, New Zealand - Environmental Pollution 171: 126-132.

[28] Schenck, R. C., Ostrom, M., Granatstein, D., Painter, K., Kruger, C. (2008): Life cycle assessment of wheat grown in Washington State. Abstract 248-253. - In: Nemecek, T., Gaillard, G. (eds.) Proceedings of the 6th International Conference on LCA in the AgriFood Sector, Zurich, November 12-14.

[29] Sleeswijk, A. W., van Oers, L. F. C. M., Guinée, J. B., Struijs, J., Huijbregts, M. A. J. (2008): Normalisation in product life cycle assessment: An LCA of the global and European economic systems in the year 2000 - Science of the Total Environment 390: 227-240.

[30] Syp, A., Jarosz, Z., Faber, A., Borzęcka-Walker, M., Pudełko, R. (2012): Greenhouse gas emissions from winter wheat cultivation for bioethanol production in Poland - Journal of Food, Agriculture and Environment 10(3-4): 1169-1172.

[31] Wattiez, C, Williamson, S. (2003): Pesticide use reduction in working: An assessment of national reduction strategies in Denmark, Sweden, the Netherlands and Norway. Pesticides Action Network Europe.

[32] Weber, R., Bujak, H., Kaczmarek, J., Gacek, E. (2011): Analysis of yield variability in winter wheat cultivars in South-Western Poland. - Bulletin of Plant Breeding and Acclimatization Institute 260/261: 121-133. 